\title{
Re/-Production:
}

\section{Identity, Queer, and Labor in the Work of Angela Mitropoulos \\ Jovita Pristovšek}

lecturer at the A.V.A., Academy of Visual Arts Ljubljana,

and a PhD student at the Post-graduate School in Nova Gorica, Slovenia

(jovitapristovsek@gmail.com)

\begin{abstract}
:
The following paper analyses the status of identity, queer, and labor in relation to re-/production, as shown in the recently published book by Angela Mitropoulos, entitled Contract and Contagion. From Biopolitics to Oikonomia (2012). The aim of this paper is to suggest that oikonomia, as elaborated by Mitropoulos, is a biopolitical heterosexual oikonomia, where we should emphasize its necropolitical intensification that reaches beyond the border of the biopolitical, meaning that it literally breeds death (necro), or in other words, the state reproduces itself by extracting the surplus value from death and war machines. The above transformation will be - in reference to the formulation of Marina Gržinić - called "necropolitical intensification of biopolitics" - while at the same time pointing also to two triads of reproduction of capital/sex/labor and race that are the one of necessity/contingency/value and the other of debt/risk/law of value. My intention is to show how the sexual reproduction is incorporated into the capitalist system through the maximization of the theory of value.
\end{abstract}

Keywords: Bio/-Necropolitics, Re/-Production, Oikonomia, Identity, Labour

\section{Biopolitics and Necropolitics}

The increase of the new forms of expropriation, precarity, indebtedness, social and economic deaths as well as consecutive discriminations, nowadays, exceeds the very term of Foucault's conceptualization of biopolitics as a governmental practice since the $18^{\text {th }}$ century onwards and its attempts to rationalize the problems and phenomena characteristic of the population (e.g. fertility, hygiene, health, race, etc.). Foucault defined biopolitics in parallel to the explanation of liberalism that he labeled as "govern too much." ${ }^{1}$ Biopolitics applies, as Foucault has said, to the type of rationalities "carried into effect in the procedures regulating human behavior through the state administration," ${ }^{2}$ or put differently, to the procedures that nowadays exceed mere control and regulation of production and reproduction of life within the frame of institutions of punishment and discipline. Hence, present "types of rationalities" are not only retreating in favor of the sphere of corporations (i.e. privatization), but are ever more, as argued by Gržinić, stepping away from the very horizon of the production of life. ${ }^{3}$ Gržinić elaborates that this biopolitical radicalization of the processes, operational in extreme conditions and produced by capital, in the field of theory as "necropolitical intensification of biopolitics," ${ }^{4}$ repoliticizes the concept of biopolitics of Michel Foucault and Giorgio Agamben in combination with the concept of necropolitics of Achille Mbembe, while simultaneously clearly distinguishing the two. Gržinić writes: '[i]f biopower, according to Foucault, is the exercise of the power 'to make live and let die,' then necropower is the exercise of the power 'to let live and make die."'s

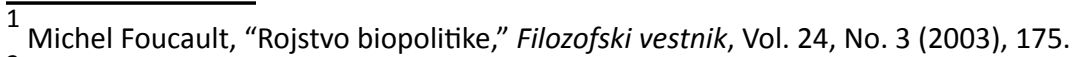

2 Ibid.175..

3 Marina Gržinić, “Capital, Repetition," Reartikulacija, No.8 (December 2009), http://www.reartikulacija.org/?p=695 (Accessed: February 23, 2013).

5 Ibid. Emphasis in the original.
} 
The difference between the biopolitics and necropolitics consists in the fact that whereas the former includes the production of life, the production of life in the latter is completely abandoned. ${ }^{6}$ Foucault's concept of biopolitics denotes the management of life within the capitalist nation-state context of the first world in the 1970s of the past century, and Agamben's contribution to biopolitics of the 1990s points to the fragmentation of life into bare life, which later on proves to be merely one of the forms in the sequence of the capitalist modes of life. ${ }^{7}$ Achille Mbembe, with his necropolitics defines "contemporary forms of subjugation of life to the power of death." ${ }^{\prime 2}$ Within this frame Mbembe discusses less abstract and more tangible categories, such as life and death, through the relation between politics and death in those systems that can operate only in state of exception. ${ }^{9}$ Upon the experience of Africa, Mbembe reads the (contemporary) politics as the "work of death"10 based on Foucault's notion of sovereignty, and their relation towards war and biopower, whilst simultaneously pointing out that the notion of biopolitics proves insufficient for the explanation of the "new and unique forms of social existence in which vast populations are subjected to conditions of life conferring upon them the status of living dead."11 His concerns are, therefore, "those figures of sovereignty whose central project is not the struggle for autonomy but the generalized instrumentalization of human existence and the material destruction of human bodies and populations." ${ }^{12}$

This "necropolitical intensification of biopolitics," is "the work of the right of the sovereign" to kill (either the corporal, or the social) under the flag of (permanent) state of exception, within which, according to Subhabrata Bobby Banerjee there is a 'legitimate' state violence. The latter enables necrocapitalism ${ }^{13}$ an access to unbridled process of accumulation. ${ }^{14}$ The process at issue will likely become evident if we try to understand how the "dispensability of human life, ${ }^{15}$ originating from the specific form of commodity, human-slave, ${ }^{16}$ connects to the triads of necessity/contingency/ value (therefore to the transformation of contingency into necessity, defining the value). Angela Mitropoulos in the book Contract and Contagion. From Biopolitics to Oikonomia, ${ }^{17}$ as well as in her shorter paper "Legal, Tender" ${ }^{18}$ shows that capitalism and its method of production of value-through, as we could say, ontological category of exploitation (of labor force)-is a triad of debt/risk/law of value. There is, therefore, the question of debt (as a necessity), risk (as contingency), and value (as the law of value) where the law of value is tied to the labor or labor force, or, in other words, to the extraction of the surplus value that is, as suggested by Mitropoulos, exercised in the field of production and re-production through the contractual and oikonomical.

\section{Identity}

What does contract and contagion in the work of Mitropoulos refer to? The notions of contract and contagion revolve around the issue of generation, relation, and subjectivity. ${ }^{19}$ For her, the relation between the contract and contagion

6 Gržinić, "Capital, Repetition."

7 Marina Gržinić, “Europe: Gender, Class, Race," The Scholar \& Feminist Online (Special Issue on Feminist Media Theory: Iterations of Social Difference), Iss. 10.3 (Summer 2012), http://sfonline.barnard.edu/feminist-media-theory/europe-gender-class-race/0/ (Accessed: April 3, 2013).

8 Achille Mbembe, “Necropolitics," Public Culture, Vol. 15, No. 1 (Winter 2003), 39-40. http://racismandnationalconsciousnessresources.files. wordpress.com/2008/11/achille-mbembe-necropolitics.pdf (Accessed: March 13, 2013).

9 Ibid.,14-16..

10 Ibid.,16.

11 Ibid., 40. Emphasis in the original.

12 Ibid.,14. Emphasis in the original.

13 Banerjee's concept of necrocapitalism is developed on the basis of the notions of sovereignty and biopower of Giorgio Agamben, Achille Mbembe and Michel Foucault. The term necrocapitalism denotes the contemporary forms of organizational accumulation that includes expropriation and submission of life to the power of death. Subhabrata Bobby Banerjee, "Live and Let Die: Colonial Sovereignties and the Death Worlds of Necrocapitalism," Borderlands, Vol. 5, no.1 (2006), http://www.borderlands.net.au/vol5no1_2006/banerjee_live.htm (Accessed: January 12, 2013).

14 Subhabrata Bobby Banerjee, "Histories of Oppression and Voices of Resistance: Towards a Theory of the Translocal," Reartikulacija, No.9, (December 2009), http://www.reartikulacija.org/?p=612\&langswitch_lang=en (Accessed: February 18, 2013).

15 Walter D. Mignolo, "Dispensable and Bare Lives: Coloniality and the Hidden Political/Economic Agenda of Modernity," Human Architecture: Journal of the Sociology of Self Knowledge, Vol. 7, Iss. 2, Article 7 (2009), 69-88.

16 Walter D. Mignolo, The Darker Side of Western Modernity: Global Futures, Decolonial Options (Durham \& London: Duke University Press, 2011), 5-6.

17 Angela Mitropoulos, Contract and Contagion: From Biopolitics to Oikonomia (Autonomedia, Minor Compositions: Brooklyn/US, 2012).

18 Angela Mitropoulos, "Legal, Tender," Reartikulacija, No. 7 (December 2009), http://www.reartikulacija.org/?p=698 (Accessed: March 2, 2013).

19 Mitropoulos, Contract and Contagion, 13-14. 
is both, figurative as well as empirical. Mitropoulos states that she cares about the illumination of the history and the practices of the actually existing "contracts as the allocation of risk" and "contagion as the field of the valorization of contingency." ${ }^{20}$ The contract, according to Mitropoulos, is -in this case-the most appreciated principle of capitalism, whose specific problem is the conversion of contingency into necessity (the reorganization of uncertainty, its re-location, or its valorization and re-introduction of necessity). ${ }^{21}$ The contract, as she states, was, legally and philosophically at the center of conflicts about the pattern and the meaning of relations, sexual and economic, denoting the gender distinction as well as the complicated connection of the public and intimate spheres. ${ }^{22}$ It served as the foundation of the social, determining the legal lines of obligation and rights. ${ }^{23}$ The contractual theory, as Mitropoulos says, is a kind of a holy trinity: of value, exchange, and surplus. ${ }^{24}$ Mitropoulos notices violence of rights in Jean Jacques Rousseau's keen advocacy: his "social compact [contract]," requires an "unanimous consent," where "no one, under any pretext whatsoever, can make any man a subject without his consent.". ${ }^{25}$ It's about a kind of a blind date, a non-voluntary subjugation, as Rousseau has reduced the coincidence of birth and residency to an anticipated act of consent, so the one who does not agree with the sovereign authority, or opposes this social contract of a nation-state, becomes a "foreigner-by-choice." ${ }^{26}$ Put shortly, and as Mitropoulos shows, it is about (in relation to Rousseau's social compact as universalized) a transformation of the contingency of birth and residency into necessity of the anticipated (or even enforced) act of consent. ${ }^{27}$

In her text with the title "Legal, Tender" (the title is a technical term for a type of a contractual debt ensured by violence) that can be found in a slightly modified version as the third chapter in the book Contract and Contagion, Mitropoulos writes primarily about the ban of the Belgrade Pride Parade in 2009. What we have there, she argues, is not legal, nor illegal, but extralegal violence. ${ }^{28}$ The rights, as she says with reference to Walter Benjamin's formulation of two forms of violence, is always accompanied by violence, either the contract - establishing, or the contract-maintaining violence. In reference to the ban of the Belgrade Pride Parade in 2009, Mitropoulos points to a new, third form of violence, the violence that does not concern the contract at all.

While elaborating on the question of human rights and democracy in relation to the legal/juridical frames, Mitropoulos, demonstrates that the deprivation of rights from the very beginning accompanies the doctrine of human rights. In other words, basic human rights practically do not exist, for if they do, then their violation is included in the judicial frame from the very beginning. Mitropoulos points out that what is at issue in the procedures of inscription in the genealogy of the state and its judicial frame (assuring its order) is the legal form of value (therefore in extreme cases decisionmaking also about what is legal labor, or put in a different way, the difference between the waged labor and slavery), a legal/judicial regulation of relations (amongst other things deciding about what authorized reproduction is going to be) and last but not least a legal form of identity (enabling individuals to prove his or her identity). "What passes for legal tender is a convention for the reckoning of debts - and a legitimated violence steps in where convention fails," ${ }^{29}$ that will, amongst other things, decide also about who and/or what is included in the legal frame (as legal or illegal) and who and/or what is excluded from it (as the out-of-law). The identity therefore shows itself as a judicial category, established through the contractual, regulating identity, valorizing its value, exchange, and the surplus.

The key for Mitropoulos's analysis is the concept of oikonomia describing the methods, through which the politics of a household (familiarity and genealogy, the intimate and national) "are crucial to the organization of intimate forms of self-management, but also the conflations of nation, race and sexuality with re-/production that continue to define the reach and limits of contractualism." ${ }^{30}$ Oikos is an ancient Greek word for household (and not for a family; family is genea, and connects the lineage or origin with generation; the modern Greek term for a family is oikogeneia, combining the notions of genealogy and a household). ${ }^{31}$ It was for Aristotle and other contemporaries, according to Mitropoulos, that the term of oikonomia denoted the study of the management of a household. Oikos was juxtaposed to polis, and

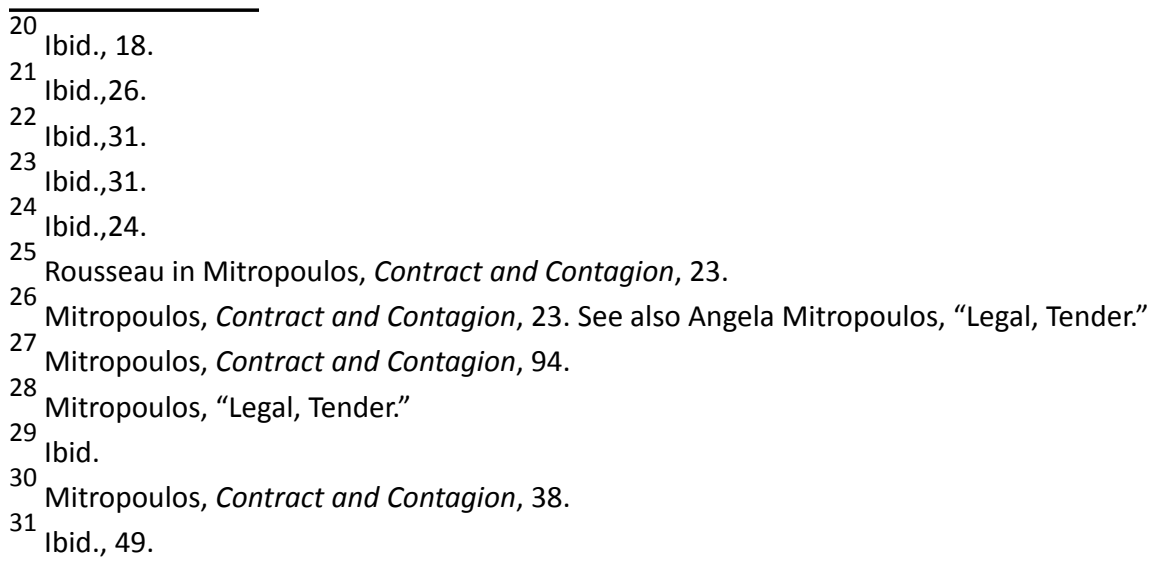


oikonomia to politikon. For Aristotle, the household (oikos) is the foundation of polis (a city state), provided that the owners of a household (within which there reigns a strict hierarchy) are free adult men (that are equal in a polis). ${ }^{32}$ In a word, here Mitropoulos speaks about the difference between the "egalitarian logic of politics" and "hierarchical logic of oikos," ${ }^{\prime 3}$ pointing with oikonomia to the shifting definitions and demarcations between economics and politics, and observing the methods with which the restoration of genealogical lines sets as the central one, for the re-foundation and persistence of the capitalist order. ${ }^{34}$ She follows the historical discontinuity between the ancient and modern understanding of oikos, in order to historize what momentarily appears to be a naturalized configuration of intimacy and genealogy, but also to simultaneously emphasize some implicit questions, posed by the history of interruptions. ${ }^{35}$ Mitropoulos argues that "geopolitical demarcations [that] come to assume the character of a domestic space (as in the familial concept of the nation, or as with the term 'domestic economy'), while the positing of distinctions such as race and class to a space outside discrete households both amplifies the perception of the household as the foundation of an ostensibly natural economy founded on a similarly naturalized sexual difference that, in turn, becomes the premise which links sex to the reproduction of race, nation and (conceived as an identity) class." ${ }^{36}$

The modern genealogical understanding of oikos has, according to Mitropoulos become a naturalized foundation, hence a model for identification and transferability of the property and right. The ancient household could not be perceived as a family home, as for the presence of slaves. For the slaves and women whose common denominators are the race and sex (and private property) in the sphere of the ancient political there was no space. ${ }^{37}$ In short, as she puts it, it concerns important shifts and the difference between the ancient oikonomia and the modern household economics: "[w]here the ancients distinguished between economics and politics and located the former in the household and where, across the eighteenth to nineteenth centuries, the household and factory were affectively and architecturally demarcated, Fordism and the Keynesian welfare state put them back together as a form of social accounting in the register of the family wage." ${ }^{38}$

Xenophon's work on oikonomia (Oeconomikos), which undergoes Latin transliteration in the Renaissance, and Aristotle's work (on the distinction between oikos and polis as a foundation for the later discussions about political economy (Foucault, Arendt), according to Mitropoulos, highlight an important question: about the household as the place of the emergence of the intimate self-management. ${ }^{39}$ This is one thing, and the second one is that Xenophon's text gains importance, especially with Machiavelli's understanding of oikos as genealogic and contractual, as he was dealing with the legal inscription of paternal rights through a contract. ${ }^{40}$ In short, "if Aristotle wrote of formal distinctions between the city-state and the oikos, Xenophon was concerned with a highly stylized managerialism, one premised on selfdiscipline, and capable of moving between city (and battlefield) and household with ease."11

In short, at the basis there is a question of (re-)production (therefore a connection of sexuality and economy) and extraction, maximization of the surplus value, which is hidden within the notion of surplus labor: either as slavery or unpaid domestic household labor, "in the presentation of surplus labor as obligation, indebtedness and gift through definitions of contract as a species of unbreakable covenant, in the presumption of contract as the performance of voluntary submission, reciprocity and exchange, and in the divisions of labor as the attributions of gender, race, citizenship and sexuality, that are arranged and characterized as the naturalized order of the oikos." ${ }^{42}$

\section{Queer}

Let's go back to the aforementioned text and chapter in "Legal, Tender;" as soon as Mitropoulos explains oikonomia as the space where economics and politics intertwine (and capitalism constantly wanting to separate them), she presents the racial and sexual reproduction as the moving nexus between the intimate and national, the public and private, between sexuality and economics as well as between the intimate and global reorganization of labor. The text "Legal,

\footnotetext{
32 Mitropoulos, Contract and Contagion, 49.

33

bid., 58.

Ibid., 50.

35 Ibid., 50 .

36 Ibid., 50.

37 Ibid., 51.

38 Ibid., 51

39 Ibid., 53.

40 Ibid., 56.

41 Ibid., 58. Emphasis in the original.

42 Ibid., 66. Emphasis in the original.
} 
Tender" opens with Pierre Nora's quotation about genealogy and the origin itself as a pure myth (we have already said that in her book Mitropoulos illustrates how at the time of Renaissance, the reading of Xenophon's oikonomia genealogically appears where it had not been before). Mitropoulos understands genealogy as the main methodology of inscription, and re-inscription of the lines of the legal production and reproduction, ${ }^{43}$ as well as the transformation of the numerous and irreducible relations into contractual identities, or to state this at the point, as the recognition "to whom or what we owe our existence." ${ }^{44}$

"[T]here would be no way to think of a race, or a people, or a nation," as Mitropoulos says, "without the ordered inscriptions of genealogy," that has brought along also the "normative economy of sex, gender and sexuality." 45 The norm is therefore the reproduction of race, and nationalism is realized through genealogy. Nationalism, as she shows, almost literally defines the rights, and it is more than just their preliminary condition. ${ }^{46}$ In this way, opposing nationalistic visions is understood as a refusal of reproduction of values representing the foundation of a nation's identity. In reference to Alys Eve Weinbaum, Mitropoulos tells us that it is about a race/reproduction link, where the "interconnected ideologies of racism, nationalism, and imperialism rest on the notion that race can be reproduced." ${ }^{47}$ Racism, nationalism and imperialism therefore cannot be thought of without their close connection to the legal/judicial frame (and contractually ensured).

It is exactly this strong inclination towards reproduction that Mitropoulos recognizes also in the claims for the recognition of rights of homosexual couples (marriage, adoption, access to the technology of bio-medically-assisted procreation etc.). ${ }^{48}$ On the reverse side of this inclination there is a question of how to ensure genealogical order, ${ }^{49}$ how to regulate the legal inscription and the assignment of proprietorship. In Slovenia, in March 2012, there was a referendum about a new Family Code that failed, however showing not only that a major portion of the space has to either emancipate from the Christianity, patriarchal and heterosexual matrix. It should be seen as the signal to wake up from the (overly) comfortable passivity (i.e. depoliticization) when the issue is the rights of fellow citizens, but also that the homosexually oriented partners are able to register only in the form of heterosexual (and therefore patriarchal) matrix. It's similar to the already mentioned figures of "foreigner-by-choice" of Rousseau. In this case, the figure of the foreigner is that of a citizen with reference to Ariella Azoulay's ${ }^{50}$ critique of the exclusive rights as a normative heterosexual citizen.

It is an issue of border, where at the attempts of its transgression the genealogical re-appears ever again in its modified forms. ${ }^{51}$ In her book, in a chapter entitled "Reproducing value," Mitropoulos gives a couple of examples of the mentioned genealogical in a modified form. While the first talks about ball houses of drag culture, whose tenants are families, most often consisting of Latin and Afro-American queer persons, gathered around the "mother of the house" or "father of the house," who "operate not only as the performative enactments of conventional gender and familial roles in a queer register," but are at the same time also staging of both, the contract and the oikos, the latter consists in more than mere "shaky foundations of the oikonomic." 52 Should the barebacking subculture represent the unprotected sexual intercourses between the HIV positive gays, who have, through the virus, found out that they can breed without women and where "the generation of the virus takes the place of reproduction," 53 and where the "culture of breeding the virus composes itself not only as a question of generation and fraternal kinship, but also invokes the contractual allocation of risk and the performativity of contract," ${ }^{\prime 4}$ then this risk no longer represents the domain of life, but the domain of death. This presents as well an - we could say Agambenian - division of oikonomia from within, the separation of the heterosexual oikonomia from the homosexual one. The latter, the homosexual oikonomia as a question of reproduction of the deadly virus coincides with what Gržinić elaborates in reference to Foucault, Agamben and Mbembe as necropolitical intensification of biopolitics. What this means for the relation of politicization/ historicization between biopolitics/necropolitics and oikonomia/lineage/nation is to be seen in the very near future.

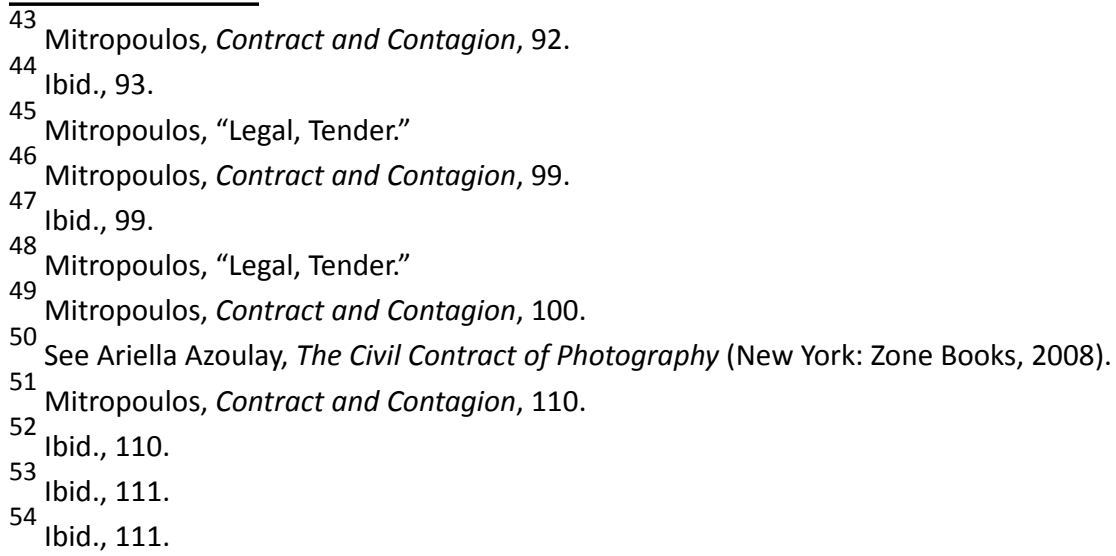


Mitropoulos in the text "Legal, Tender" elaborates on the contractual theory of Benedict de Spinoza, and the tension between the common and the private - in other words, "between the jealous privatisation of women as the object of desire and women as the common property of men," the tension that operates as "the template of contract theories, whether those of the marital, wage or social contract, and brings to the fore all the gendered senses in which the categories of active and passive (citizenship and sexuality) are constructed and remade," 55 adding that, "it is little wonder that both [Étienne] Balibar and [Warren] Montag, in reading Spinoza to this point, begin to think about the trans-Atlantic slave trade. There is, very simply, no way to think of sexual economies without speaking, also, of the organisation of race, though the connection is less metonymic or homologous than that they are both crucial to the inscriptions of genealogy, the legitimate transmission of property through name." ${ }^{56}$

What sums it up is the notion that "the household (reproductive) architecture of a Jeffersonian domestic economy required common law's experimental inclination and its scalable contracts. At the frontier, sovereignty and canonical law gave way to fraternal democracy and common law. ${ }^{157}$ According to Mitropoulos, they represent a frontier expansion; the oceanic expansion of an empire and common law. "Common law," as she puts it, "with its reliance on case law, unfolds through a subtle play between precedent and approximation - or, put another way, common law navigates power through repetition and variation." ${ }^{\prime 5}$ It is the heteronormative household (or, in other words the heteronormative matrix) that, she continues, was the one that has, based on a precedent, and the evolution of the common law itself, decided about the time and quantity measure of the recognition of property, contract, loans, their inheritability and assurance. ${ }^{60}$

Here Mitropoulos adds another statement of Siobhan B. Somerville, who does not say only that the idea of advanced nations should be only the bestowment of authenticity to the identity itself, and the introduction of comparison, and that the politics of identity are insufficient when we speak about race, but that the inter-racial marriage became introduced with its complete heterosexualization. ${ }^{61}$ Referring to Janet Halley, Mitropoulos adds that the "[m]ovements around sexual orientation, [...] harbor 'an unforgivingly corrosive critique of identity itself."' 62 She also argues "that the specificity of queer sex is that it, as with the Marxian notion of class, is far less an identity than a placeholder of that which is regarded as without value, inauthentic and - in its specifically capitalist sense - deemed unproductive or excessively so." ${ }^{63}$ She here speaks about queer value that she places "between the putatively abstract schema of money and the apparently particularistic organization of an oikonomics." ${ }^{64}$ The term queer was, according to Will Fisher originally used in phrases connected to falsification, or forged money since the $17^{\text {th }}$ century (all the way until the $19^{\text {th }}$ century).$^{65}$ So the value of the queer addresses the issue of authenticity in the sense of a forgery, or imitation of heterosexuality, ${ }^{66}$ as well as the question of the authenticity of the movement itself. Fisher explores, as argued by Mitropoulos, "in his treatise of the etymological proximity of 'queer sex' to 'queer money,' their shared connotations of counterfeit and forgery." ${ }^{\prime \prime}$ If each original requires its copy (reproduction) in order to define, evaluate one's own authenticity, or, in other words, if the copy grants authenticity, then the queer shows itself as a consisting part of capitalism. But as Mitropoulos says "[w] ithout 'the guarantee of power,' as Mark Osteen puts it, 'counterfeit and genuine currency are identical,', ${ }^{\prime 68}$ pointing that Osteen shows to the dependence of monetary economy upon the 'faith' or 'belief' in authenticity. ${ }^{69}$

\section{Labor}

Genealogy inscribes itself through a precedent or an approximation of the authorization of the state in the gesture of granting authenticity (either to a race, labor, sex, etc.) with the help of stories about the origin within the frame of

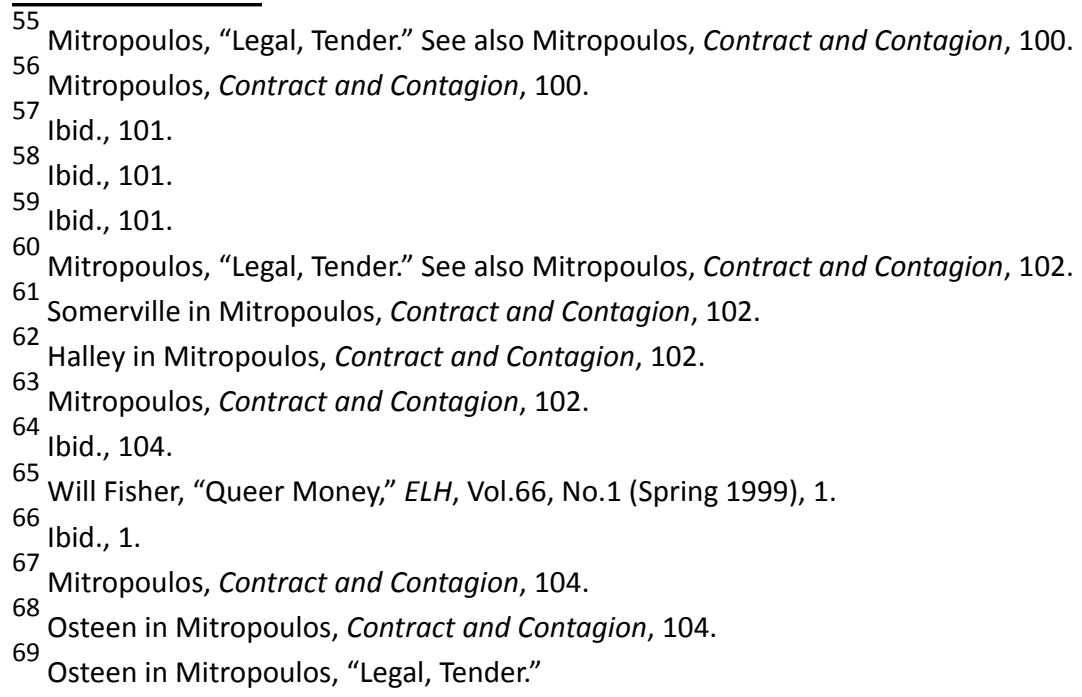


common law; it is "in the unpredictable environment of life" (as said by judge Wendell Holmes), ${ }^{70}$ or in other words, in the endless sequence of states of exception and the transmission of exceptional rules into the legal/judicial frame that "their re- and productivity in relation to a nation state is (re)defined." reference to Mitropoulos at the beginning of the analysis, is a type of debt, and the debt is arranged on the basis of the contractual, and assured by violence.

There is a question of how to intensify the surplus labor as a point of class re-composition ${ }^{72}$ through, as argued by Mitropoulos, "indistinction between intimacy and economy that plays out, among other things, as the expectation that women who work [...] deliver a labor that has affective purchase, circulating as an extension of [...] care-giving domestic labor that has to appear as if it is not work at all, but freely and naturally given." ${ }^{\prime 73}$ This is therefore a story of capitalism whose key question concerns the surplus labor and its channeling as well as the re/distribution through oikonomia ${ }^{74}$; it is a brutal law of value where the place of the surplus labor is tied to the surplus value, and where exploitation is shown as an ontological category. The latter, according to Mitropoulos, constitutes the central logic of capitalist (re-)production that also includes unpaid household work as the domain of femininity, and slavery as the domain of blackness. ${ }^{75}$

The labor force itself does not, according to Mitropoulos, represent an ontological, but a historical category. It does not represent the synonym for bare life, saying that it is more likely the judgment of common law about what is just and what is not: "The remainder, the surplus of the labor theory of value, is that which is not recognized as labor, as being productive. [...] The labor theory of right is, in its way, a way of recording the genealogies of exploitation and recompense - quite literally, tracing the lines of justice and indebtedness, of adjudicating on the not-so-confident assumption of knowing to whom and to what we owe our existence." ${ }^{\prime 76}$

If today it is the debt that produces surplus value - as also shown by Marina Vishmidt in one of her discussions on debt as the present foundation for social reproduction ${ }^{77}$ - or, in other words, should the debt "translates ownership into obedience," 78 post-Fordism could be read as an updated version of slavery. This is what Mitropoulos virtually hints to when saying: "Not only is the labor of the slave without measure, it is situated outside time in the supposedly mutual and sentimental bonds of master and slave, but nevertheless figured as a boundless obligation to labor. Slavery, rather than wage labor, is the riddle (and telos) at the heart of the labor theory of value - or, better put: it marks the extraction of a surplus without punctual limit, through the gendered, racialised distribution of the wage and its accompanying architectures of household and nation." ${ }^{79}$

Unwaged labor is, according to Vishmidt, also anchored in the wage relation itself, hiding "the unpaid, slave-like nature of so much of the work upon which capital accumulation is premised." 80 But to point to the noticeable difference, inherent to a contemporary slave, we should add - to the already mentioned - her shattering statement that today "[c]apital has neither the inclination nor the resources to offer workers more exploitation right now, but there has to be recognition that exploitation remains the bedrock of the social contract, and it is achieved most efficiently without jobs in an economy premised on the capitalization of debt." ${ }^{81}$ The loss of social antagonism should be, according to Vishmidt ascribed to the moment of devalorization of labor and its revalorization in the form of debt, where the devalorization itself (both, the ideological as well as the economic) ensures that the social field in its entirety confronts the capital. The worker, on the other hand, is shown as a unit of capital, that can either represent an input (when given modal life, i.e. life with form, style, etc.) or subject to exploitation (as indebtedness represents his/her only access

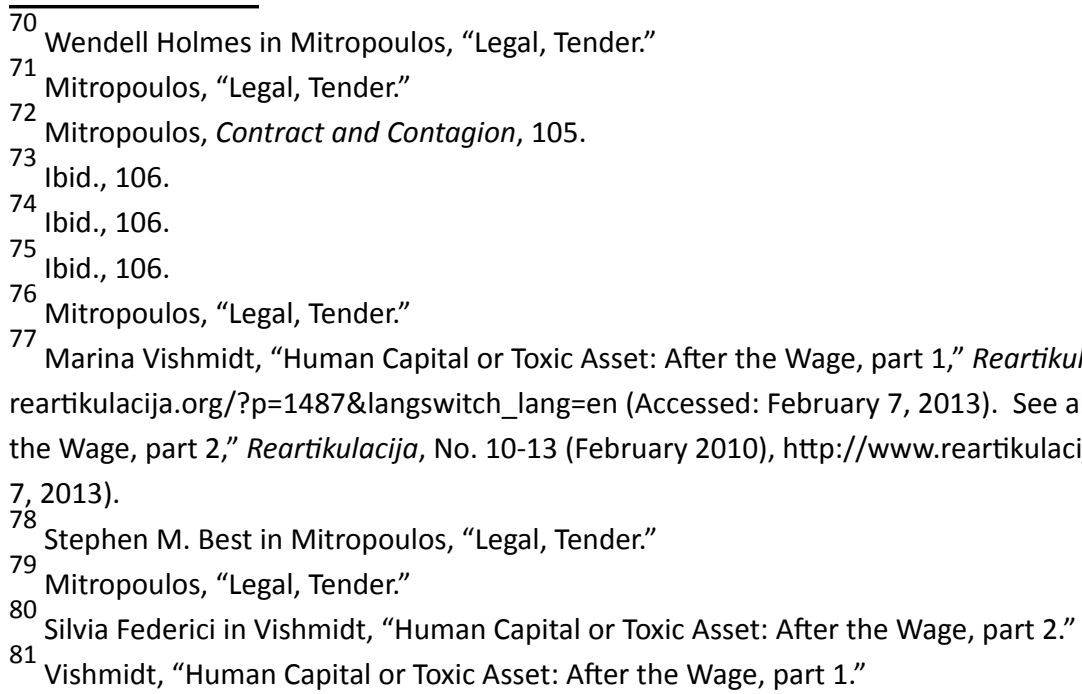


to the basic necessities of life). ${ }^{82}$ So it may not be so surprising that Mitropoulos also claims that she has a feeling that the globally spread protests, movements, and occupations of today represent an economic opposition rather than political formations; something that could not be ascribed to them in the 1960s - an economic maximalism and political minimalism. ${ }^{83}$

\section{Coda}

Capitalism has - to the last drop - succeeded in incorporating the sexual reproduction into the system of its value as labor (sex work, social work in the forms of custody, fostering, and adoption into nuclear, extended, or reorganized families, service work as care labor, etc.), or as consumption and exhaustion (the systems of identities). Capitalism has incorporated sexual reproduction into the very center of the system through the maximisation of the theory of value (i.e. through maximisation of surplus labor), and showed that genealogy represents the sliding door, opening or closing according to historical requirements.

Despite its repeating representation in connection to identities and singular branded sexual practices, sexual reproduction, at a closer look, really shows itself as the central place of the reproduction, hegemony, and discrimination. Sexual reproduction is inscribed into the biopolitics of the neoliberal capitalist state when operating as the most desired biopolitical dispositive (especially through the formation of genealogies), or it is the dispositive of necrocapitalistic procedures (e.g. former Yugoslavia).

The ban of the Belgrade Pride Parade as a deprivation of rights accompanied by extralegal (violence) that Mitropoulos writes about is the matter of the necropolitical and not of the biopolitical.

Jovita Pristovšek (1982) 2008 graduated in fine arts at The Academy of Fine Arts, Ljubljana, Slovenia, where she also finished MA in fine arts. She is currently enrolled in the PhD program at the Post-graduate School in Nova Gorica, Slovenia working on her PhD thesis entitled The regimes of Aesthetic, Public, and Political within the Post-political Global Space. From 2009, she teaches at the A.V.A. Institute, Ljubljana.

\section{Bibliography:}

Azoulay, Ariella. 2008. The Civil Contract of Photography. New York: Zone Books.

Banerjee, Subhabrata Bobby. 2006. "Live and Let Die: Colonial Sovereignties and the Death Worlds of Necrocapitalism." Borderlands, Vol. 5, no.1. http://www.borderlands.net.au/vol5no1_2006/banerjee_live.htm (Accessed: January 12, 2013).

Banerjee, Subhabrata Bobby. 2009. "Histories of Oppression and Voices of Resistance: Towards a Theory of the Translocal." Reartikulacija. No. 9.

http://www.reartikulacija.org/?p=612\&langswitch_lang=en (Accessed: February 18, 2013).

Fisher, Will. 1999. „Queer Money.« ELH, Vol. 66, No.1. 1-23.

Foucault, Michel. 2003. “Rojstvo biopolitike." Filozofski vestnik, Vol. 24, No. 3. 171-177.

Gržinić, Marina. 2009. “Capital, Repetition.” Reartikulacija. No. 8.

http://www.reartikulacija.org/?p=695 (Accessed: February 23, 2013).

\footnotetext{
$\overline{82}$ Marina Vishmidt, "Value at Risk: From Politics of Reproduction to Human Capital," Reartikulacija, No. 7 (December 2009), http://www. reartikulacija.org/?p=708 (Accessed: March 5, 2013).

83 Angela Mitropoulos, February 25, 2013, "A summary of sorts," http://s0metim3s.com/2013/02/25/cc-summaryofsorts (Accessed: March 22, 2013).
} 
Gržinić, Marina. 2012. "Europe: Gender, Class, Race." The Scholar \& Feminist Online (Special Issue on Feminist Media Theory: Iterations of Social Difference), Issue 10.3.

http://sfonline.barnard.edu/feminist-media-theory/europe-gender-class-race/0/ (Accessed: April 3, 2013).

Mbembe, Achille. 2003. “Necropolitics." Public Culture, Vol. 15, No. 1. 11-40, http://

racismandnationalconsciousnessresources.files.wordpress.com/2008/11/achille-mbembe-necropolitics.pdf

(Accessed: March 13, 2013).

Mignolo, Walter D. 2009. "Dispensable and Bare Lives: Coloniality and the Hidden Political/Economic Agenda of Modernity." Human Architecture: Journal of the Sociology of Self Knowledge, Vol. 7, Iss. 2, Article 7. 69-88.

Mignolo, Walter D. 2011. The Darker Side of Western Modernity: Global Futures, Decolonial Options. Durham \& London: Duke University Press.

Mitropoulos, Angela. 2009. "Legal, Tender." Reartikulacija, No.7.

http://www.reartikulacija.org/?p=698 (Accessed: March 2, 2013).

Mitropoulos, Angela. 2012. Contract and Contagion. From Biopolitics to Oikonomia. Minor Compositions: Brooklyn/ US: Autonomedia.

Mitropoulos, Angela. February 25, 2013. "A summary of sorts." http://sOmetim3s.com/2013/02/25/ccsummaryofsorts (Accessed: March 22, 2013).

Vishmidt, Marina.2009. "Value at Risk: From Politics of Reproduction to Human Capital." Reartikulacija, No. 7. http:// www.reartikulacija.org/?p=708 (Accessed: March 5, 2013).

Vishmidt, Marina. 2010. "Human Capital or Toxic Asset: After the Wage, part 1." Reartikulacija, No. 10-13. http://www.reartikulacija.org/?p=1487\&langswitch_lang=en (Accessed: February 7, 2013).

Vishmidt, Marina. 2010. "Human Capital or Toxic Asset: After the Wage, part 2." Reartikulacija, No. 10-13. http://www.reartikulacija.org/?p=1492\&langswitch_lang=en (Accessed: February 7, 2013). 